\section{Antimicrobial Activity and Synergism of Lactoferrin and Lysozyme Against Cariogenic Microorganisms}

Flaviana Bombarda de Andrade ${ }^{1}$, Jair Caetano de Oliveira ${ }^{2}$, Marjorie Takei Yoshie $^{2}$, Bruno Martini Guimarães ${ }^{1}$, Rafael Braga Gonçalves ${ }^{3}$, Waleska Dias Schwarcz ${ }^{4}$
'Department of Dentistry, Endodontics and Dental Materials, Bauru School of Dentistry, USP - University of São Paulo, Bauru, SP, Brazil

${ }^{2}$ School of Dentistry, UNOPAR - North Paraná University, Londrina, PR, Brazil ${ }^{3}$ Biochemistry Department, Biomedical Institute, UNIRIO - Federal University of the State of Rio de Janeiro, Rio de Janeiro, RJ, Brazil ${ }^{4}$ Leopoldo de Meis Medical Biochemistry Institute, Structural Biology Program, Rio de Janeiro, RJ, Brazil

Correspondence: Profa. Dra. Flaviana Bombarda de Andrade, Alameda Octávio Pinheiro Brisolla, 9-75, 17012-901 Bauru, SP, Brasil. Tel: +55-14-3235-8344. email: flaviana@fob.usp.br

Key Words: lysozyme, lactoferrin, dental caries, Streptococcus mutans, Lactobacillus casei.

\section{Introduction}

There are many determining factors to dental caries, some of them related to saliva and bacterial colonization on the dental biofilm. Saliva protects oral tissues in many ways. A constant flow of saliva eliminates accumulations of microorganisms from the oral cavity but saliva also contains many innate or acquired (antibodies) defense mechanisms (1).

One of the unspecific immunological factors (innate) is antimicrobial proteins: lysozyme, lactoperoxidase system, lactoferrin, high weight molecular glycoproteins and other salivary components that can act as bacterial aglutinines (2-4). Innate human salivary defense proteins such as lysozyme, lactoferrin and peroxidase are known to exert a wide antimicrobial activity against a number of bacterial, viral and fungal pathogens in vitro (1).

The majority of these proteins can inhibit the metabolism, adherence or even the viability of the cariogenic microorganisms in vitro. Many unspecific immunological factors can interact with the antibodies (specific factors), resulting in mutual amplification of their respective activities $(4,5)$.

Mutans streptococci and lactobacilli are microorganisms with known cariogenic capacities (6-8). The first is considered an etiological agent of carious lesions and is able to produce (acidogenic) and tolerate (aciduric) high quantities of lactic acid, and the second is considered particularly involved in the progression of carious lesions $(8,9)$. Mutans streptococci and lactobacilli have been correlated positively with caries prevalence and caries increment and the existence of saliva-caries relationships have been reported (1,10-12).

The aim of this study was to evaluate, in vitro, the antimicrobial effects of the proteins lactoferrin and lysozyme on reference cultures of the microorganisms Streptococcus mutans and Lactobacillus casei, using the agar diffusion and broth macrodilution methods, in order to obtain their minimum inhibitory concentration (MIC) and minimum bactericidal concentration (MBC), individually or synergistically.

\section{Material and Methods}

The experiments were performed at the Microbiology Laboratory of the North of Paraná University. Culture media Brain-Heart Infusion (BHI; Difco, Detroit, MI, USA) broth and agar were made. The tubes and the plates were 
processed in autoclave, tested for their sterility and kept under refrigeration.

The solutions of lysozyme and lactoferrin (Sigma Chemical $\mathrm{Co}$, Saint Louis, MO, USA) were obtained as powder weight on an analytical balance (Tecnal, Piracicaba, SP, Brazil) and diluted with ultra pure water in a volumetric balloon, and stored as aliquots in micro tubes and refrigerated at $-20^{\circ} \mathrm{C}$.

Reference cultures of the microorganisms $S$. mutans (ATCC 25175) and L. casei (ATCC 7469) were used. These microorganisms, previously frozen, were reactivated in sterile $\mathrm{BHI}$ broth and were incubated at $37{ }^{\circ} \mathrm{C}$ in a carbon dioxide chamber (TE-399; Tecnal). After $48 \mathrm{~h}$ of culture growth, the Gram stain method was done and cultures were re-plated, in order to verify their purity.

The transference of the microorganisms to broth media was performed, and they had their absorbance index verified hourly in a spectrophotometer (Biomate 3; Thermo Scientific, Madison, WI, USA) in wavelengths of $540 \mathrm{~nm}$. The absorbance numbers were utilized to create the graphics (Fig. 1). The log phase of bacterial growth or exponential growth period (about $6 \mathrm{~h}$ after transference) was the chosen moment for the antimicrobial test.

In the agar diffusion test, Petri dishes were filled with layer of Miller-Hinton agar and afterwards, they received the microbial inocula spread in BHI broth, standardized via a spectrophotometric reading.

Sterile filter-paper disks received $10 \mu \mathrm{L}$ of the solutions lactoferrin or lysozyme, in respective concentrations of $200 \mu \mathrm{g} / \mathrm{mL}$ and $80 \mu \mathrm{g} / \mathrm{mL}$. They were then placed over the agar surface in equidistant positions. Four plates were used: two of them contained the inoculum of S. mutans. One contained filter-paper disks saturated in the solution lysozyme, the other saturated in the solution lactoferrin. The two remaining plates contained L. casei. One was used to verify the inhibition by lactoferrin and the other by lysozyme. The plates remained in room temperature for $2 \mathrm{~h}$ to diffuse the antimicrobial substances through the agar, before the microbial growth could occur. Finally, the plates were incubated at $37^{\circ} \mathrm{C}$ for $48 \mathrm{~h}$ in a carbon dioxide chamber. These procedures were executed in triplicate.

In the broth macrodilution, 16 tubes with $1 \mathrm{~mL}$ of $\mathrm{BHI}$ broth were used for each bacterial species, eight for each protein, numbered from 1 to 8 . According to the calculations, the concentrations of the proteins in each tube were determined as shown in Table 1.

After preparation of the tubes, the standardized bacterial inocula of $5 \times 10^{5} \mathrm{CFU} / \mathrm{mL}$ (colony forming units per $\mathrm{mL}$ of medium), established via readings in a spectrophotometer, were introduced into each tube. The tubes were incubated at $37^{\circ} \mathrm{C}$ for $18 \mathrm{~h}$ in a carbon dioxide chamber. After this period, the tubes had their absorbance numbers verified in the spectrophotometer to analyze the turbidity caused by bacterial growth and obtain the MIC.

In this sequence, $50 \mu \mathrm{L}$ of the tube contents were transferred onto Petri dishes $(15 \times 60 \mathrm{~mm})$ with $\mathrm{BHI}$ agar. After being spread on the plates, they were incubated at $37^{\circ} \mathrm{C}$ for $18 \mathrm{~h}$. Next, the plates were analyzed in order to verify the bactericidal activity. This experiment was also done in triplicate.

The susceptibility test of associated antimicrobial proteins followed the same protocol of the broth macrodilution method and was done only for the S. mutans. Inside tube number one, $4 \mathrm{~mL}$ of lactoferrin at $200 \mathrm{mg} /$ $\mathrm{mL}$ and $2 \mathrm{~mL}$ of lysozyme at $150 \mathrm{mg} / \mathrm{mL}$ were added. From this tube, a serial dilution was made. The inoculum of $S$. mutans was then transferred to each tube of dilution. The final concentrations of lactoferrin and lysozyme are showed in Table 2.
Table 1. Concentrations of lysozyme and lactoferrin inside the tubes of standard dilution to test the susceptibility of microorganisms

\begin{tabular}{lcccccccc}
\hline Protein & Tube 1 & Tube 2 & Tube 3 & Tube 4 & Tube 5 & Tube 6 & Tube 7 & Tube 8 \\
\hline Lysozyme $(\mathrm{mg} / \mathrm{mL})$ & 68.5 & 58.7 & 50.3 & 43.1 & 36.9 & 31.6 & 27.1 & 23.3 \\
Lactoferrin $(\mathrm{mg} / \mathrm{mL})$ & 171.4 & 146.9 & 125.9 & 107.9 & 92.5 & 79.3 & 67.9 & 58.2 \\
\hline
\end{tabular}

\section{Results}

The absorbance numbers recorded hourly in the spectrophotometer displayed the graphics of bacterial growth (Fig. 1). The start of the exponential growth of both bacteria occurred approximately in $6 \mathrm{~h}$.

In the agar diffusion test, no zone of bacterial growth

Table 2. Concentrations of lysozyme and lactoferrin inside the tubes of standard dilution to test the synergism of proteins over S. mutans

\begin{tabular}{lcccc}
\hline Protein & Tube 1 & Tube 2 & Tube 3 & Tube 4 \\
\hline Lactoferrin $(\mathrm{mg} / \mathrm{mL})$ & 66.6 & 44.4 & 29.6 & 19.7 \\
Lysozyme $(\mathrm{mg} / \mathrm{mL})$ & 16.6 & 11.07 & 7.4 & 4.9 \\
\hline
\end{tabular}

inhibition was observed, indicating absence of antimicrobial activity of both proteins in the tested concentrations.

In the broth macrodilution method, the MIC was obtained form the readings of turbidity of the culture medium with antimicrobial proteins at different concentrations. The values of absorbance and MIC are 
shown in Tables 3 and 4, respectively.

The concentration of $43.1 \mathrm{mg} / \mathrm{mL}$ of lysozyme had a bacteriostatic effect over $L$. casei, but on $S$. mutans this effect was only obtained with $58.7 \mathrm{mg} / \mathrm{mL}$.

Lactoferrin did not induce an inhibitory effect on any bacterium, even in concentrations of $200 \mathrm{mg} / \mathrm{mL}$. There were no synergic antimicrobial effects of proteins when they were tested, until concentrations of $42.8 \mathrm{mg} / \mathrm{mL}$ of lysozyme and $114 \mathrm{mg} / \mathrm{mL}$ of lactoferrin were established.

The minimum bactericidal concentration (MBC) of lysozyme was $50.3 \mathrm{mg} / \mathrm{mL}$ against $L$. casei and $68.5 \mathrm{mg} /$ $\mathrm{mL}$ against $S$. mutans.

\section{Discussion}

The overall clinical function of lysozyme and lactoferrin in the human mouth is not well documented, suggesting instead that they are important for controlling the microbial overgrowth, reducing the number of bacteria in the dental biofilm, decreasing the colonization of microorganisms and/ or modifying the bacterial metabolism $(13,14)$.

The antimicrobial activity of lactoferrin occurs via a high affinity linkage with iron, making this ion unavailable to many bacterial species. It also exerts antimicrobial activity using other mechanisms of action, such as, the direct interaction between lactoferrin and the components of bacterial cells (15). Because of this property, lactoferrin is used as a component for mouthwashes and dental creams (16).

Lysozyme is a prominent antimicrobial protein of human saliva. Lysozyme's antibacterial properties are related to its muramidase activity, leading to the degradation of the murein-containing layer of the bacterial cell wall and eventually resulting in bacterial lysis. Lysozyme activity in the oral cavity has mainly been characterized against oral streptococci and may play a protective role in oral candidosis (17).

Table 3. Absorbance index of the tubes containing the antimicrobial proteins and the microorganism

\begin{tabular}{lcccc}
\hline Tubes & $\begin{array}{c}\text { Lysozyme and } \\
\text { S. mutans }\end{array}$ & $\begin{array}{c}\text { Lysozyme } \\
\text { and L. casei }\end{array}$ & $\begin{array}{c}\text { Lactoferrin } \\
\text { and S. mutans }\end{array}$ & $\begin{array}{c}\text { Lactoferrin } \\
\text { and L. casei }\end{array}$ \\
\hline 1 & 0.120 & 0.106 & 1.589 & 1.080 \\
2 & 0.214 & 0.080 & 1.575 & 1.083 \\
3 & 0.767 & 0.173 & 1.402 & 1.038 \\
4 & 1.209 & 0.347 & 0.734 & 0.790 \\
5 & 0.962 & 0.595 & 0.739 & 0.877 \\
6 & 1.505 & 0.903 & 0.992 & 0.796 \\
7 & 1.220 & 1.167 & 0.946 & 0.272 \\
8 & 1.749 & 1.161 & 1.341 & 0.589 \\
\hline
\end{tabular}

Felizardo et al. (18) found an association between concentrations of lactoferrin and the DMFT index (decayed, missed and filled teeth index) and a tendency of association between lysozyme concentrations and DMFT. This information corroborates the protective role of salivary proteins in the etiology of dental caries, in an indirect way. Proteins can inhibit the bacteria that can cause the dental disease.

The lactobacilli and mutans streptococci have a considerable cariogenic capacity $(7,9,11)$. Therefore, these two microorganisms were selected for tests for the present work.

The use of different antimicrobial methodologies, without standardization, provides results that cannot be compared. In the present work, the broth macrodilution and agar diffusion methods were used. It was verified that in the agar diffusion test, there was no inhibitory halo formation, corroborating the findings of Koneman et al. (19), who saw the agar diffusion test with restrictions because the correlation between the inhibition zone sizes and the MIC results of macrodilution is not in agreement.

In the present study, the microorganisms utilized were only inhibited by the antimicrobial action of lysozyme, and were not affected by lactoferrin until the concentration of $200 \mathrm{mg} / \mathrm{mL}$.

Arnold et al. (20) observed the bactericidal effect of lactoferrin on some strains of $S$. mutans, at the concentration of $83 \mu \mathrm{M}$, which correspond to $6.64 \mathrm{mg} / \mathrm{mL}$. These concentrations are much lower than our results, which could be explained by the methodological differences. L. casei was not inhibited by lactoferrin in both studies, because this bacterial growth can be stimulated by this protein.

Lactoferrin does not only inhibit the growth of many pathogenical bacteria, but it also stimulates the growth of certain types of bacteria (21). According to Kim et al. (22), lactoferrin presents a prebiotic effect, promoting the growth of the probiotic bacteria L. acidophilus and Bifidobacterium spp. and they also suggest that there

Table 4. Concentration of the proteins that showed antimicrobial action $(\mathrm{mg} / \mathrm{mL})$

\begin{tabular}{lcc}
\hline Solutions & MIC & MBC \\
\hline Lysozyme and L. casei & Tube 4: 43.1 & Tube 3: 50.3 \\
Lysozyme and S. mutans & Tube 2: 58.7 & Tube 1: 68.5 \\
Lactoferrin and L. casei & - & - \\
Lactoferrin and S. mutans & - & - \\
Lysozyme + lactoferrin and L. casei & - & - \\
Lysozyme + lactoferrin and S. mutans & - & -
\end{tabular}


are other lactoferrin-binding proteins, which promote the bacterial growth stimulation of lactoferrin. This could explain why lactoferrin did not inhibit $L$. casei, but it could not explain why S. mutans was not inhibited.

Lysozyme from different sources were tested by lacono et al. (23), against some strains of S. mutans, and they found that human lysozyme was more effective than hen egg white Lysozyme, however, many authors, have used this, because the facilities of extractions and good correlations with human lysozyme. lacono et al. (23) showed a total inhibition of different strains of $S$. mutans by egg lysozyme at a concentration of $5 \mathrm{mg} / \mathrm{mL}$, a lower value than our concentrations. They also stated that different mechanisms may be responsible for the bacteriostatic, lytic and bactericidal properties of the enzyme and that lysozyme is a selective but effective antibacterial factor for oral microorganisms.

Little is known about the interaction among lysozyme, lactoferrin, lactoperoxidase and secretory IgA (antibody) in vivo, but it is reasonable to presume that it occurs. In vitro evidence suggests that interactive effects may vary with different concentrations of the proteins involved; and salivary concentrations of lysozyme, lactoferrin, lactoperoxidase and secretory IgA show considerable variations between individuals. It is therefore likely that patterns of interactions will also vary between individuals (24). Many antimicrobial proteins contain multiple functional domains, which makes that one protein may have more than one mechanism of antimicrobial activity (17).

In the present study, the association of two enzymes did not promote a better antimicrobial effect with the concentrations utilized. It is hypothesized that the antimicrobial effects of lactoferrin and other salivary proteins are associated in a synergistic way, as immunoglobulins and inorganic compounds, also justifying the lack of inhibitory effects of lactoferrin alone.

According to Felizardo et al. (18), who found correlations among the lactoferrin and lysozyme concentrations and the caries index, it can be hypothesized that there are more interactions among these and other salivary proteins, which can influence the individual susceptibility of dental caries through antimicrobial activity. Therefore, the proteins interactions should be further investigated.

In conclusion, S. mutans and L. casei were only inhibited by lysozyme and were not affected by lactoferrin and by the synergic use of lysozyme and lactoferrin.

\section{Resumo}

0 presente estudo avaliou, in vitro, o efeito antimicrobiano das proteínas salivares lactoferrina e lisozima sobre micro-organismos envolvidos no processo carioso, obtendo suas concentrações inibitórias mínimas (CIM) e bactericidas mínimas (CBM). Cepas de Streptococcus mutans (ATCC 25175) e Lactobacillus casei (ATCC 7469) foram submetidas a macrodiluição em caldo das soluções de lisozima a $80 \mathrm{mg} / \mathrm{mL}$ e lactoferrina a $200 \mathrm{mg} / \mathrm{mL}$. A leitura dos tubos foi realizada em espectrofotômetro, após a incubação a $37{ }^{\circ} \mathrm{C}$ por $18 \mathrm{~h}$ em estufa de $\mathrm{CO}_{2}$, para verificação da CIM. Uma nova subcultura foi semeada em placas de ágar para a obtenção da CBM. 0 método de difusão em ágar foi também testado utilizando-se placas de Petri com ágar BHI com100 $\mu \mathrm{L}$ do inóculo microbiano padronizado. Discos de filtro de papel embebidos com $10 \mu \mathrm{L}$ das soluções de lactoferrina $(200 \mu \mathrm{g} / \mathrm{mL})$ e lisozima $(80 \mu \mathrm{g} / \mathrm{mL})$ foram colocados sobre a superfície do ágar. Não foi observado halo de inibição nas placas, demonstrando ausência de efeito antimicrobiano das proteínas neste teste. Os efeitos bactericida e bacteriostático da lisozima sobre $L$. casei foram $50,3 \mathrm{mg} / \mathrm{mL}$ e $43,1 \mathrm{mg} / \mathrm{mL}$ respectivamente. Os efeitos bactericida e bacteriostático sobre S. mutans foram $68,5 \mathrm{mg} / \mathrm{mL}$ e $58,7 \mathrm{mg} / \mathrm{mL}$. A lactoferrina não induziu nenhum efeito inibitório sobre nenhuma bactéria, mesmo na concentração de $200 \mathrm{mg} / \mathrm{mL}$. Não houve efeito antimicrobiano sinérgico das proteínas, quando testadas conjuntamente, e mesmo até em concentrações de $42,8 \mathrm{mg} / \mathrm{mL}$ de lisozima e $114 \mathrm{mg} / \mathrm{mL}$ de lactoferrina (os maiores valores avaliados). $S$. mutans e $L$. casei foram inibidos somente pela lisozima, não sendo afetados pela lactoferrina e pelo uso sinérgico de ambas proteínas.

\section{Acknowledgements}

This study received financial support from UNOPAR (North of Paraná University).

\section{References}

1. Hegde MN, Hegde ND, Ashok A, Shetty S. Biochemical indicators of dental caries in saliva: an in vivo study. Caries Res 2014;48:170-173.

2. Azevedo LF, Pecharki GD, Brancher JA, Cordeiro CA, Medeiros KGD, Antunes $A A$, et al.. Analysis of the association between lactotransferrin (LTF) gene polymorphism and dental caries. J Appl Oral Sci 2010;18:166170.

3. Kidd EA, Fejerskov 0. What constitutes dental caries? Histopathology of carious enamel and dentin related to the action of cariogenic biofilms. J Dent Res 2004;83:C35-C38.

4. Gillum TL, Kuennen M, Gourley C, Schneider S, Dokladny K, Moseley P. Salivary antimicrobial protein response to prolonged running. Biol Sport 2013;30:3-8.

5. Van Nieuw Amerongen A, Bolscher JG, Veerman EC. Salivary proteins: protective and diagnostic value in cariology? Caries Research 2004;38:247-253.

6. Pieri FA, Mussi MC, Fiorini JE, Moreira MA, Schneedorf JM. Bacteriostatic effect of copaiba oil (Copaifera officinalis) against Streptococcus mutans. Braz Dent J 2012;23:36-38.

7. Seki M, Yamashita Y, Shibata Y, Torigoe H, Tsuda H, Maeno M. Effect of mixed mutans streptococci colonization on caries development. Oral Microbiol Immunol 2006;21:47-52.

8. Arthur RA, Cury AA, Graner RO, Rosalen PL, Vale GC, Paes Leme AF, et al.. Genotypic and phenotypic analysis of $S$. mutans isolated from dental biofilms formed in vivo under high cariogenic conditions. Braz Dent J $2011 ; 22: 267-274$.

9. Kneist S, Schmidt F, Callaway A, Willershausen B, Rupf S, Wicht M, et al.. Diversity of Lactobacillus species in deep carious lesions of primary molars. Eur Arch Paediatr Dent 2010;11:181-186.

10. Ranadheer E, Nayak UA, Reddy NV, Rao VA. The relationship between salivary IgA levels and dental caries in children. J Indian Soc Pedod Prev Dent 2011;29:106-112.

11. Botelho MP, Maciel SM, Cerci Neto A, Dezan CC, Fernandes KB, de Andrade FB. Cariogenic microorganisms and oral conditions in asthmatic children. Caries Research 2011;45:386-392.

12. Paganini M, Dezan CC, Bichaco TR, de Andrade FB, Neto AC, Fernandes 
KB. Dental caries status and salivary properties of asthmatic children and adolescents. Int J Paediatr Dent 2011;21:185-191.

13. Berlutti F, Ajello M, Bosso P, Morea C, Andrea P, Giovanni A, et al.. Both lactoferrin and iron influence aggregation and biofilm formation in Streptococcus mutans. Biometals 2004;17:271-278.

14. Oho T, Mitoma M, Koga T. Functional domain of bovine milk lactoferrin which inhibits the adherence of Streptococcus mutans cells to a salivary film. Infect Immun 2002;70:5279-5282.

15. Jenssen $H$, Hancock REW. Antimicrobial properties of lactoferrin. Biochimie 2009;91:19-29.

16. Tenovuo J. Clinical applications of antimicrobial host proteins lactoperoxidase, lysozyme and lactoferrin in xerostomia: efficacy and safety. Oral Dis 2002;8:23-29.

17. Edgerton M, Koshlukova SE. Salivary histatin 5 and its similarities to the other antimicrobial proteins in human saliva. Adv Dent Res 2000;14:16-21.

18. Felizardo KR, Gonçalves RB, Schwarcz WD, Poli-Frederico RC, Maciel $\mathrm{SM}$, Andrade FBD. An evaluation of the expression profiles of salivary proteins lactoferrin and lysozyme and their association with caries experience and activity. Rev Odonto Ciên 2010;25:344-349.
19. Koneman EW (cols.). The anaerobic bacteria. In: Color atlas and textbook of diagnostic microbiology. 6th ed. Philadelphia: Lippincott;2006. p. 878-938.

20. Arnold RR, Brewer M, Gauthier JJ. Bactericidal activity of human lactoferrin: sensitivity of a variety of microorganisms. Infect Immun 1980;28:893-898.

21. Mitsuoka T. Bifidobacteria and their role in human health. J Ind Microbiol 1990;6:263-267.

22. Kim WS, Ohashi M, Tanaka T, Kumura H, Kim GY, Kwon IK, et al.. Growth-promoting effects of lactoferrin on L-acidophilus and Bifidobacterium spp. Biometals 2004;17:279-283.

23. lacono VJ, MacKay BJ, DiRienzo S, Pollock JJ. Selective antibacterial properties of lysozyme for oral microorganisms. Infect Immun 1980;29:623-632.

24. Rudney JD, Smith OT. Relationships between levels of lysozyme, lactoferrin, salivary peroxidase, and secretory immunoglobulin-A in stimulated parotid-saliva. Infect Immun 1985;49:469-475.

Received May 22, 2013 Accepted April 17, 2014 